\title{
SUPORTE TEXTUAL, COERÊNCIA E PRODUÇÃO DE SENTIDOS: DISCUSSÃO A PARTIR DE TEXTOS DE MÍDIA DE AMBIENTE
}

\author{
MEDIUM, COHERENCE AND PRODUCTION OF MEANING: A DISCUSSION BASED \\ ON OUT-OF-HOME MEDIA PIECES
}

Juliana de Mello Chagas Lima ${ }^{1}$, Edson Carlos Romualdo ${ }^{2}$

\begin{abstract}
Resumo: Este artigo tem como ponto de partida a observação da existência de novos espaços para a publicação de peças publicitárias, em especial o uso de diferentes suportes e formatos. Nosso objetivo, neste trabalho, é contribuir para a discussão sobre a importância dos suportes na construção dos sentidos dos textos, principalmente no que se refere à sua coerência, com base em autores como Marcuschi (2003; 2008), Koch (2009), Koch e Travaglia (2011), Bonini (2011), entre outros. Analisamos textos da chamada "mídia de ambiente", uma vertente da criação e veiculação publicitária, que tem como característica a instalação de peças publicitárias em locais inusitados e de grande fluxo de pessoas. Consideramos que essas novas formas de publicidade permitem novas relações para a produção de sentidos, devido à interação com o ambiente físico em que estão inseridas e as relações entre sujeitos e objetos promovidas a partir de sua publicação, levando-nos a propor o suporte como um dos fatores de coerência.
\end{abstract}

Palavras-chave: linguística textual; suporte; mídia de ambiente.

\section{Considerações iniciais}

Quando andamos pelos grandes centros urbanos, muitas vezes nos sentimos inundados por uma enorme quantidade de estímulos de publicidade. Há luminosos, há outdoors, há, muitas vezes, propaganda onde menos esperamos encontrar, como no interior de restaurantes, em elevadores, no transporte público e até em banheiros. Todas essas manifestações de propaganda podem ser entendidas como uma maneira de chamar a atenção de um público consumidor cada vez menos atento e menos disposto a se voltar para os produtos ofertados.

\footnotetext{
${ }^{1}$ Mestre e doutoranda no Programa de Pós-Graduação em Letras da Universidade Estadual de Maringá (PLE/UEM), na linha de Estudos do Texto e do Discurso. Tradutora (Inglês-Português), com foco em material corporativo e textos publicitários.

${ }^{2}$ Mestre e doutor em Letras pela Universidade Estadual Paulista Júlio de Mesquita Filho (Unesp/Assis). Docente de Linguística nos cursos de Letras e EAD Letras e de Linguagem no curso EAD Pedagogia e professor do Programa de PósGraduação em Letras. Coordenador do projeto interinstitucional Gêneros discursivos, material didático e novas tecnologias. Integra dois grupos de pesquisa inscritos no CNPq: GEPOMI - Grupo de Estudos Políticos e Midiáticos e Linguagem e Direito.
} 
Os meios tradicionais de comunicação, como os jornais, rádio e televisão, têm sofrido uma perda de popularidade e, olhados por uma perspectiva comunicacional, uma perda de eficácia. Por isso, têm sido criados mecanismos para driblar essa nossa defesa, como é o caso de uma modalidade inovadora no fazer publicitário: a mídia de ambiente.

A mídia out-of-home $(\mathrm{OOH})$, ou mídia de ambiente, é uma vertente da criação e veiculação publicitária explorada por autores como Himpe (2006) e Covaleski (2008). Essa forma de mídia tem como premissa o fato de que "qualquer coisa" pode ser utilizada como um veículo para a publicidade, e pode estar presente em locais de grande fluxo de pessoas, proporcionando impacto visual por seu tamanho e ampliando a visibilidade, ao surgir de maneira e em locais inesperados e estar situada em local estratégico.

A mídia de ambiente, por suas características próprias, instiga-nos a pensar nas formas de circulação dos textos em nossa sociedade atual, principalmente sobre o papel dos suportes em sua constituição, pois o lócus físico e a produção de sentidos nessa mídia estão, em alguns casos, intrinsecamente relacionados. Desta forma, nosso objetivo neste artigo é contribuir para a discussão sobre a importância dos suportes na construção dos sentidos dos textos de mídia de ambiente, principalmente no que se refere à sua coerência. Para isso, nosso percurso passa por considerações sobre os suportes, a coerência textual e a análise de três textos de mídia de ambiente. Esse percurso nos guia à apresentação de uma proposta de compreensão do suporte entre os fatores de coerência, quando pensamos no tipo de mídia do qual nos propomos tratar.

\section{O suporte}

Quando se trata da definição do papel dos suportes na constituição textual, um dos grandes obstáculos para a sua exata caracterização é o fato de não haver um conceito estável e estabelecido para esse elemento nas teorias do texto. No entanto, ao voltarmos nosso olhar para os textos que discutem o suporte na Linguística Textual no Brasil, encontramos em Marcuschi $(2003$; 2008) um ponto de partida para a sua caracterização. Para o autor, cada gênero textual tem um propósito bastante claro, que o determina e lhe dá uma esfera de circulação. Todos os gêneros têm uma forma e uma função, bem como um estilo e um conteúdo - entretanto, sua determinação se dá, principalmente, em relação à sua função (deixando a forma em segundo plano). Os suportes são compreendidos, a partir dessa relação com os gêneros, como aquilo que "porta" os gêneros, permitindo-lhes a circulação social. 
Marcuschi $(2003$; 2008) entende o suporte como um lócus físico ou virtual, com formato específico, que serve de base ou ambiente de fixação do gênero materializado como texto. Pode-se dizer que o suporte de um gênero é uma superfície física em formato específico que suporta, fixa e mostra um texto. Como explica Bezerra (2006), para Marcuschi (2003), o suporte é uma coisa, uma superfície ou objeto (físico ou virtual) que permite a manifestação concreta e visível do texto. Assim, para Marcuschi, a ideia de suporte abarcaria três aspectos: a) O suporte é um lugar (físico ou virtual); b) O suporte sempre tem formato específico, como um livro, uma revista, um jornal, um outdoor. Para Marcuschi (2003; 2008), o fato de ser específico significa que foi comunicativamente produzido para portar textos, não sendo um portador eventual; e c) O suporte serve para fixar e mostrar o texto.

A partir desses pressupostos, vemos surgir outros trabalhos sobre os suportes, por exemplo, o de Bonini (2011), que amplia a discussão ao contrastar os conceitos de "suporte" e "mídia" na circulação dos gêneros, entendendo "mídia" como o elemento essencial nessa relação e "suporte" como componente material da mídia. Para o autor, a definição do que vem a ser o suporte ainda é uma questão em aberto nos estudos da linguagem e da comunicação, pois vários conceitos se confundem, contrapondo-se ou sobrepondo-se.

Para embasar suas propostas a respeito do tema, o autor apresenta três momentos de caracterização do conceito de suporte. Em primeiro lugar, revê as ideias de Marcuschi (2003), que foi, como dissemos, quem abriu o debate e trouxe alguns parâmetros para as discussões que estariam por vir. Em um segundo momento, Bonini reconsidera suas próprias posições anteriores, de Bonini (2005), em que via o suporte como portador de textos, de diferentes formas, que se hibridizavam. Por último, traz algumas ideias a partir das discussões de Távora (2008), cujo principal foco é a diferenciação entre suporte e gênero.

Bonini (2011) se inspira no fato de Debray (1991) ter trazido as sustentações teóricas iniciais, na década de 1990, para a conceitualização do termo suporte, com base nas ideias de Marshal McLuhann (1964) e seu entendimento da relação complexa e intrincada entre "meio" e "mensagem". Conforme Bonini (2011), Debray (1991), apesar de não permitir uma precisão em relação aos conceitos de suporte e mídia, contribui positivamente para a questão teórica, entendendo o suporte como um "componente do médium", a partir do que Bonini conclui que o suporte vem a ser parte da mídia. No contexto da mídia de ambiente, essa ideia faz sentido, ao considerarmos o suporte uma parte constituinte das peças que pertencem a essa modalidade de comunicação.

Segundo Bonini, deve-se entender como "mídia" o elemento contextualizador, no interior do qual o gênero circula, ou seja, um processo tecnológico de mediação e interação 
linguageira. Para ele, portanto, o suporte seria um elemento material (de registro, armazenamento e transmissão de informação na mídia) que intervém na concretização dos três aspectos caracterizadores de uma mídia: formas de organização, produção e recepção. As mídias, então, apresentariam um conjunto de suportes encadeados na forma de um sistema.

Bonini nos permite uma visão ampla sobre essas relações, mas na qual o suporte não seria o elemento mais diretamente relacionado ao gênero como unidade da interação, mas, sim, um componente da mídia. Para o autor, o uso do termo suporte só seria relevante em uma análise mais pormenorizada de uma mídia específica, exatamente o que pretendemos nesse artigo. A partir dessas considerações, entendemos que nossa proposta se centraliza no estudo de suportes de uma mídia específica - a mídia de ambiente, com destaque para as suas relações com a coerência dos textos publicitários.

Ainda na problematização sobre os suportes a partir das ideias de Marchuschi, podemos citar, por exemplo, Costa (2008), que faz uma análise de algumas das proposições iniciais de Marcuschi (2003), em parte contrariando a afirmação de que todo texto tem um suporte: a autora entende ser complicado determinar os suportes dos textos orais, concluindo que a afirmação se refere a todos os textos escritos, mas não a todos os textos orais. Para a autora, o suporte é uma categoria pertinente para o estudo dos textos escritos e multimodais que, na sua percepção, incluem figuras, fotos, gráficos, infográficos, tipografias diversas. Assim, assevera que todo texto escrito (ou multimodal) tem um suporte (COSTA, 2008, p. 190, grifo nosso), o que seria a condição de sua circulação.

Para tal questão, recorremos ao tema da multimodalidade, que tem vindo à tona nos estudos mais recentes sobre o texto. A análise de textos de modalidades de linguagem que extrapolam o verbal, sob uma vertente da Linguística do Texto, é realizada, por exemplo, por Romualdo (2000; 2013; 2014), que defende, mais especificamente em Romualdo (2014), que não se pode restringir a compreensão do texto e dos conceitos ao tratamento somente de textos verbais. Para o autor, muitos conceitos podem ser ampliados ou deslocados para o tratamento de textos de várias materialidades, posição que seguimos neste artigo.

Maingueneau (2013) ainda associa a ideia de que não basta, quando se trata de um mídium de um gênero de discurso, levar em conta seu suporte material no sentido estrito (oral, escrito, manuscrito, televisivo etc.). O texto é inseparável do seu modo de existência material.

Posição semelhante também está presente em Cavalcante e Custódio Filho (2010), que se voltam para a discussão sobre os conceitos de texto. Ao questionar qual seria o papel dos elementos não verbais, os autores apresentam a percepção sobre a necessidade de se considerar a materialidade textual não só por seus aspectos verbais, mas também os não 
verbais, com um olhar multimodal sobre as estratégias textual-discursivas. Dessa forma, propõem que a natureza multifacetada do texto comporte, em sua constituição, "a possibilidade de a comunicação ser estabelecida não apenas pelo uso da linguagem verbal, mas pela utilização de outros recursos semióticos" (CAVALCANTE; CUSTÓDIO FILHO, 2010, p. 64).

Os autores entendem que haja uma abertura de caminho para que as investigações nesse sentido se desdobrem para textos que não tenham um caráter exclusivamente verbal. Ao escolhermos a mídia de ambiente como objeto de análise, fazemos exatamente isso, lançando nosso foco sobre o suporte e sua relação com textos multimodais, visto que todas as peças publicitárias analisadas se enquadram como multimodais.

Esses autores dão base para o posicionamento apresentado nesse artigo, pois nossas observações partem do escopo teórico da Linguística Textual, para analisarmos peças publicitárias de mídia de ambiente que, devido às suas especificidades, condicionam a produção e recepção dos textos. As características da mídia de ambiente e o recorte do suporte como o lócus físico nos conduzem à distinção que Marcuschi $(2003$; 2008) faz entre os suportes convencionais, aqueles que foram elaborados tendo em vista a sua função de portarem ou fixarem textos, como os livros, revistas ou jornais, e os suportes incidentais, ou seja, as mais variadas superfícies. Aliás, o autor ressalta que toda superfície física pode, em alguma circunstância, funcionar como um suporte - e, destacamos, isso tem sido cada vez mais comum na paisagem urbana: suportes ocasionais ou eventuais, ou seja, incidentais, que têm uma possibilidade ilimitada de realizações com os textos escritos.

Dentre os exemplos de suportes incidentais trazidos pelo autor, chamam à atenção aqueles que fazem parte da vida urbana, como paradas de ônibus, estações de metrô, calçadas, fachadas, janelas de ônibus. Por essa perspectiva, haveria, portanto, uma diferenciação entre os suportes convencionais e os suportes incidentais, que se daria pelo fato de serem ou não criados para portar mensagens publicitárias. Essa diferença fica clara quando se trata da distinção entre um anúncio em uma revista, entendida como um suporte convencional, e o uso de um objeto, como os equipamentos de musculação, para anunciar um produto, entendendoo como suporte incidental: algo inusitado, que será utilizado uma vez, para uma campanha específica.

No entanto, há situações em que a propaganda é claramente uma peça de mídia de ambiente, que, em tese, utilizaria suportes não convencionais, mas está colocada em um suporte previamente determinado para receber propaganda. É o caso de alguns anúncios instalados em banheiros ou em aeroportos, que já têm um local, tamanho e formato pré- 
determinados pelas empresas que prestam exatamente o serviço de oferecer espaços para publicação de mensagens em ambientes não-convencionais. Por esse fato, acreditamos que esses locais não possam ser considerados suportes incidentais.

Para explicarmos essa relação, vemos necessidade de trazermos para nossa discussão os conceitos de mídia tradicional e mídia alternativa (na qual está inclusa a mídia de ambiente). Encontramos em Públio (2008) uma diferenciação que se baseia exatamente na relação da propaganda com o seu suporte. Para o autor, a diferença entre mídia tradicional e a não-convencional está exatamente aí: a tradicional utiliza um meio pré-estabelecido como suporte para a difusão da informação, enquanto a no media, ao contrário, cria seu próprio suporte. Essa perspectiva toca em um ponto importante para nossa discussão: a "criação" de um suporte. Na nossa visão, podemos entender essa criação como uma integração do suporte à propaganda, que também é abordada por Himpe (2006), que estuda a integração da mensagem de propaganda com a função do objeto que atua como suporte dela.

Himpe (2006), ao tratar sobre a utilização do valor funcional dos objetos na mídia de ambiente, afirma que a maioria dos espaços que contém propaganda não tem outra função, senão a de propaganda, mas há itens do dia-a-dia que são utilizados como suporte de propaganda que têm outras funções: caixas de pizza, cabines de banheiro, provadores de loja. Pode acontecer de esses objetos se descaracterizarem dessas funções, tornando-se, exclusivamente, suportes para a propaganda, porém, em outros casos, os objetos podem continuar exercendo suas funções, ao mesmo tempo em que exibem campanhas publicitárias. Isso nos leva a abordar, também, a terceira afirmação de Marcuschi (2003, 2008), de que o suporte serve para fixar e mostrar o texto.

Assim, podemos elaborar alguns questionamentos em torno da afirmação de Marcuschi (2003; 2008), de que o suporte é fixo e produzido especificamente para portar textos. Nas peças publicitárias de mídia de ambiente, é comum encontrarmos objetos do diaa-dia sendo utilizados como suporte. A figura a seguir retrata diversos locais, em um ambiente interno, que podem ser escolhidos e transformados em suporte, onde podem ser instaladas peças de propaganda de mídia de ambiente. A peça faz parte de uma campanha de uma empresa de mídia indoor, chamada Enox, que anuncia seus próprios serviços mostrando que todo lugar pode ser um bom lugar para anunciar: o chão, a parede, a máquina de chopp, a calça do garçom. 


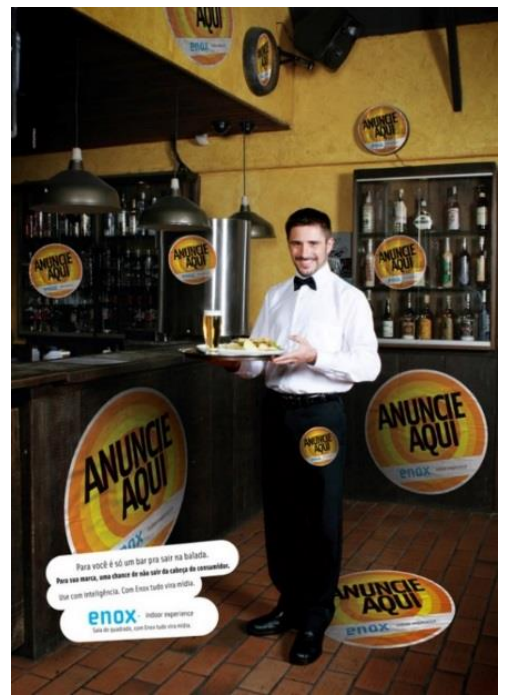

Figura 1 - Campanha Enox: locais que podem se transformar em suportes

Desta forma, entendemos que o suporte é imprescindível para que o gênero circule na sociedade. Marcuschi (2003, 2008), apesar de afirmar que o suporte tem um formato específico e é convencionalizado, firmando ou apresentando o texto para que se torne acessível, e que não deve ser confundido com o contexto ou a situação, nem com o canal em si, nem com a natureza do serviço prestado, conclui também que o suporte não deixa de operar como um tipo de contexto - assim, não fica indiferente ao gênero suportado, mas tem influência sobre ele. Para o autor, o suporte afeta a leitura (MARCUSCHI, 2003): o mesmo texto publicitário fixado num outdoor ou inserido em uma revista semanal será lido de formas diferentes, de acordo com o seu suporte, pois a relação do leitor com o suporte interfere na sua relação com o texto.

Sobre esse assunto, também discorre Maingueneau (2013), defendendo que o mídium (na concepção do autor, o modo de difusão de um gênero) não seja um simples "meio" de transmissão do discurso. Para ele, o mídium imprime um certo aspecto a seus conteúdos e comanda os usos que dele podemos fazer, além de ser um instrumento para transportar uma mensagem estável. Assim, uma mudança importante do mídium modifica o conjunto de um gênero de discurso. Podemos perceber que a função do suporte não se limita, portanto, a exibir um texto. Na verdade, o suporte não só permite a circulação do texto como contribui para a construção do seu sentido.

\section{O papel da coerência na constituição textual}


Os sete critérios de textualidade propostos por Beaugrande e Dressler, na obra Introduction to Text Linguistics (1981) - coesão, coerência, situacionalidade, informatividade, intertextualidade, intencionalidade e aceitabilidade - funcionam como princípios constitutivos da comunicação textual, envolvendo fatores de cognição, planejamento e ambiente social para caracterizar o que constitui um texto. Esses princípios são a base para os estudos de autores brasileiros na área da Linguística Textual, como Koch (2009), Koch e Travaglia (2011), Bentes (2008) e Marcuschi (2008), que os tomaram como ponto de partida para suas reflexões e os ampliaram, seja acrescentando itens à lista, seja com a intenção de compreender e reavaliar suas relações hierárquicas, ou mesmo a sua obrigatoriedade para a definição da textualidade. É claro que essas posições são fundamentadas na análise dos critérios com base nas transformações dos estudos linguísticos que se deram nas décadas posteriores à sua publicação, com foco, principalmente, em uma abordagem interacional da língua.

Para Marcuschi (2008), os critérios não têm todos o mesmo peso, nem a mesma relevância para a textualidade, e não se distinguem de maneira tão clara quanto aparentam. Entretanto, mostram o quão rico é um texto em seu potencial para conectar atividades sociais, conhecimentos linguísticos e conhecimentos de mundo. Eles fazem do texto uma possibilidade, "uma proposta de sentido [que] só se completa com a participação do seu leitor/ouvinte" (MARCUSCHI, 2008, p. 94).

Em Koch (2009) também se apresentam algumas críticas à definição dos critérios, pois ela entende o texto em sua dimensão interacional. Destacam-se dois pontos principais: o primeiro, o de que não faz sentido a divisão entre critérios "centrados no texto" e "centrados no usuário" (KOCH, 2009, p. 43). A visão defendida pela autora é a de que todos os critérios estão centrados, simultaneamente, no texto e nos seus usuários. Afinal, não se pode ignorar o fato de que a textualidade está sustentada sobre três pilares: o produtor do texto (autor), o leitor (receptor) e o texto em si (o evento comunicativo). Em segundo lugar, a autora nota que a coerência não pode ser considerada apenas um critério de textualidade entre os demais. Ela é, na verdade, o resultado da confluência de todos os demais fatores de textualidade. Para a autora, a coerência resulta de uma construção dos usuários do texto, numa dada situação comunicativa, para a qual contribuem, de maneira relevante, todos os critérios de textualidade apresentados.

Fávero e Koch (1985) acrescentam, à lista de critérios propostos por Beaugrande e Dressler (1981), mais um elemento: a argumentatividade. As autoras defendem que, para que um conjunto de enunciados venha a constituir um texto coerente, é preciso que nele seja mantida uma intenção e que esta seja reconhecível por parte dos parceiros. E não há como 
negar que essa seja a principal característica a ser considerada quando se trata de analisar textos publicitários, nosso objeto aqui, que têm como princípio constituinte a intenção de persuadir.

As críticas e questionamentos levantados por Fávero, Koch e Marcuschi, nos estudos apontados anteriormente, servem como um ponto de partida para buscarmos uma compreensão sobre o papel da coerência no funcionamento da textualidade, e sua relação com a argumentatividade. Faz parte dessa discussão o conceito de interpretabilidade, proposto por Charolles (1983), como sendo a possibilidade de se estabelecer um sentido para o texto, e que está diretamente ligado à coerência textual. Para Charolles (1983), a coerência pode ser entendida como um princípio de interpretação das ações humanas de um modo geral e, consequentemente, como um princípio de interpretação do discurso. Como uma atividade interpretativa, e não uma propriedade imanente ao texto, está ligada, principalmente, a atividades cognitivas, ficando suas relações com o código em segundo plano.

Assim, é possível compreender a coerência como aquilo que faz com que o texto faça sentido para os usuários, estando ela ligada à inteligibilidade do texto numa situação de interação e à capacidade que o receptor tem para calcular o sentido desse texto. Neste momento, nossa discussão se amplia para entendermos o papel da coerência para a constituição dos sentidos e, como consequência, seu papel na constituição dos textos.

A coerência é, em boa parte, uma atividade realizada pelo receptor de um texto, que atua sobre a proposta do autor. Ela se estabelece na interlocução, na interação entre dois usuários numa dada situação comunicativa. Beaugrande e Dressler (1981) já compreendiam essa relação, afirmando ser a coerência não só uma característica dos textos, mas o resultado de processos cognitivos entre os usuários. Para os autores, a simples justaposição de eventos e situações em um texto ativará operações que recuperam ou criam relações de coerência.

Ao contrário da coesão, que trata das propriedades formais do texto - de seus elementos linguísticos -, a coerência se diferencia por tratar dos procedimentos pelos quais os elementos do conhecimento são ativados. Ela é considerada, portanto, um princípio da interpretabilidade, dependente da capacidade dos usuários de recuperar o sentido do texto pelo qual interagem. Ela pode ter limites variáveis para o mesmo usuário, dependendo da situação, e para usuários diversos, dependendo de vários fatores, como os conhecimentos que ele possui e a sua disposição em compreender um texto, por exemplo. Tudo depende, conforme explica Charolles (1983), da interação entre usuários e da capacidade do receptor de interpretar as indicações presentes no texto para que, finalmente, consiga compreendê-lo de 
uma forma que pareça coerente para ele, ou seja, de uma forma que corresponda à sua ideia do que torna uma série de ações um todo integrado.

A coerência é, sobretudo, uma relação de sentido que se manifesta entre os enunciados, em geral, de maneira global e não localizada. Na verdade, a coerência providencia a continuidade de sentido no texto e a ligação dos próprios tópicos discursivos. Não é observável como fenômeno empírico, mas se dá por razões conceituais, cognitivas, pragmáticas e outras. (MARCUSCHI, 2008, p. 121)

Percebemos que entender o texto como o resultado de uma ação linguística - cujas fronteiras são, em geral, definidas por seus vínculos com o mundo no qual ele surge e funciona, conforme explica Marcuschi (2008) - é fundamental para analisarmos as possibilidades de produção de sentido em textos da mídia de ambiente. Afinal, o texto não pode ser entendido como uma simples sequência de palavras, mas como um evento "multimodal" (MARCUSCHI, 2008, p. 80) que envolve, em seu processamento, aspectos linguísticos e não-linguísticos.

Sob esse aspecto, torna-se fundamental também entendermos a relação dos elementos verbais de um texto com os elementos não-verbais. Conforme comenta Romualdo (2014), era comum, no início dos estudos textuais, pensar-se o texto somente a partir da linguagem verbal. Contudo, o leque de materiais que são objeto de interesse no campo da Linguística Textual tem se diversificado. Muitos trabalhos apresentados atualmente, pertencentes ao domínio dos estudos do texto, não são compostos exclusivamente pelo elemento verbal, mas apresentam também em sua materialidade outros elementos, como aspectos visuais ou musicais.

Apesar de não se ter obtido, ainda, um conceito plenamente satisfatório sobre a constituição da materialidade dos textos, podemos partir, para a sua consideração, de uma definição sobre texto, em sentido lato, proposta por Fávero e Koch (1988), que afirmam que "texto, em sentido lato, designa toda e qualquer manifestação da capacidade textual do ser humano (quer se trate de um poema, quer de uma música, uma pintura, um filme, uma escultura etc.), isto é, qualquer tipo de comunicação realizado através de um sistema de signos" (FÁVERO E KOCH, 1988, p. 25). Parece inegável, portanto, que, ao se propor um estudo do texto, admita-se a multimodalidade em sua constituição, considerando que os textos convocados para análise no âmbito das teorias do texto envolvam múltiplos elementos. Para dar conta da análise dos textos, entretanto, Romualdo (2014) defende que se recorra a outros campos do saber ou que se adapte os conceitos dos campos da linguística. 
Considerando todos esses elementos, verbais ou não verbais, entendemos o texto como um evento que atualiza sentidos, e não uma entidade portadora de sentidos, independentemente de seus leitores. Essa visão se faz necessária para analisarmos a mídia de ambiente, uma forma de propaganda que foge do tradicional, pois não é possível analisá-la restringindo-se a formas estanques e limitadas de entender o texto, mas faz-se necessário ampliar e questionar a visão tradicional sobre a sua constituição e a importância da coerência nesse processo.

Contribuindo para essa percepção, há um ponto fundamental, defendido por alguns autores, sobre a constituição da textualidade: o fato de um texto só poder ser considerado um texto caso possa ser entendido como tal pelo leitor/ouvinte. É isso o que defendem Koch e Travaglia (2011), que explicam que uma sequência de palavras ou frases é entendida como um texto somente quando aquele que a recebe é capaz de percebê-la como uma unidade significativa global. Também em Beaugrande (1997, p. 13) encontramos uma constatação similar: "um texto não existe, como texto, a menos que alguém o processe como tal"3. Assim, entendemos que a existência de um texto depende do fato de alguém processá-lo dentro de um contexto, uma posição que também é defendida por Marcuschi (2008, p. 90): "Dada configuração linguística funciona como um texto quando consegue produzir efeitos de sentido, coerência, etc., do contrário não é um texto".

Compreende-se, portanto, o texto como um evento comunicativo, do qual participam tanto o autor quanto o leitor, mas que também se encontra ancorado nas suas condições de produção e que permite, a partir da materialidade linguística, visual, musical, entre outras, a produção de sentidos. Para que esse evento comunicativo seja realizado, precisam ser combinados três aspectos, em uma "articulação multinível” (MARCUSCHI, 2008): os aspectos linguísticos (o ato de fala verbalmente produzido), os aspectos sociais (a situação sociohistórica) e os aspectos cognitivos (conhecimentos investidos). Essa visão toma como base uma noção de texto apresentada por Beaugrande (1997), na continuidade de seus estudos, que afirma ser o texto um evento comunicativo, no qual convergem ações linguísticas, sociais e cognitivas.

Assim, fica claro que perceber o texto apenas como uma combinação de palavras ou frases é uma visão limitada, pois dele também fazem parte outros elementos que devem ser considerados constitutivos da produção de sentidos. Além do papel fundamental da situação à qual o texto está ancorado - ou, conforme explica Marcuschi, seu contexto situacional, que

\footnotetext{
${ }^{3}$ No original, em inglês: A text does not exist, as text, unless someone is processing it. Tradução em Marcuschi (2008, p. 89).
} 
envolve desde as condições imediatas até a contextualização cognitiva, os enquadres sociais, culturais, históricos, entre outros - ainda se faz necessário considerar o papel essencial dos seus produtores e receptores. Quando se trata de peças de publicidade, esse modo de ver o texto é de extrema importância, pois, por se tratarem de textos que são compostos por diversos elementos, não podemos limitá-los ao aspecto linguístico ou imagético, mas sim ao contexto em que ele está situado, suas relações com o ambiente e seu suporte. O ambiente físico, principalmente na mídia de ambiente, não pode mais ser visto apenas como mero elemento das condições de produção textual, como se fosse uma moldura para os enunciados. Deve-se questionar se seu uso não vem a ser constituinte e fundamental para a construção dos sentidos.

\section{Fatores de coerência textual}

Cavalcante (2012) relembra que a coerência é um princípio de interpretabilidade, não se manifestando apenas através da decodificação dos elementos linguísticos do texto, mas também de uma série de fatores extralinguísticos e pragmáticos inerentes à construção de sentidos. Os estudos do texto trouxeram novos elementos para a compreensão da coerência, além de reordenarem, como constituintes desse princípio de interpretabilidade, os fatores levantados por Beaugrande e Dressler (1981).

Baseando-se na ideia de que a coerência textual é resultado de um processo cooperativo entre produtor e receptor, Koch e Travaglia (2011) criaram um diagrama ${ }^{4}$ que propõe um modelo de coerência textual envolvendo todos os fatores que, de alguma forma, afetam o sentido que os usuários constroem no/a partir do texto. Como apontamos anteriormente, vários dos elementos linguísticos presentes nesse diagrama coincidem com os critérios de textualidade apresentados por Beagrande e Dressler (1981): a informatividade, a intertextualidade, a situacionalidade, a intencionalidade e a aceitabilidade. Entretanto, percebemos também que esses elementos são abordados de uma maneira distinta.

A principal diferença é que a coerência não está entre esses elementos, mas é apresentada como um elemento "macro", que é constituído a partir de todos os outros. Outro ponto fundamental nesses fatores é a inclusão de elementos que se referem a questões que ultrapassam os limites linguísticos, como é o caso do conhecimento de mundo, do conhecimento partilhado, e dos fatores pragmáticos e situacionais, que estabelecem

\footnotetext{
${ }^{4}$ O diagrama de Koch e Travaglia (2011) foi adaptado e é apresentado na última parte deste artigo.
} 
possibilidades mais amplas de produção de sentidos. É a partir dessas possibilidades que consideramos, em alguns casos específicos, como na mídia de ambiente, a inclusão de novos elementos entre esses fatores, como veremos a seguir.

\section{Suporte e produção de sentidos na mídia de ambiente}

As peças publicitárias que trazemos para análises são exemplos de mídia de ambiente em que o suporte exerce, a nosso ver, um papel fundamental na constituição dos sentidos e da coerência dos textos. Na primeira encontramos uma relação intrínseca entre o suporte e o produto anunciado para produção de sentidos e da argumentação da peça publicitária. Trata-se do produto Pepto-Bismol, um medicamento antiácido, vendido nos Estados Unidos.

O suporte para essa propaganda são máquinas de lavar roupa, com abertura frontal, instaladas em lavanderias automáticas, que são típicas no país. Essas máquinas receberam adesivos na parte da frente, que retratam o corpo de uma pessoa, de forma que a abertura da máquina fique exatamente no local onde ficaria o estômago do fotografado. Nessas peças, o sentido é produzido a partir do efeito da roupa girando na máquina de lavar e da espuma do sabão, que simulam a sensação de "estômago embrulhado", sintoma que levaria uma pessoa a tomar o medicamento, como podemos verificar pela Figura 2, a seguir:

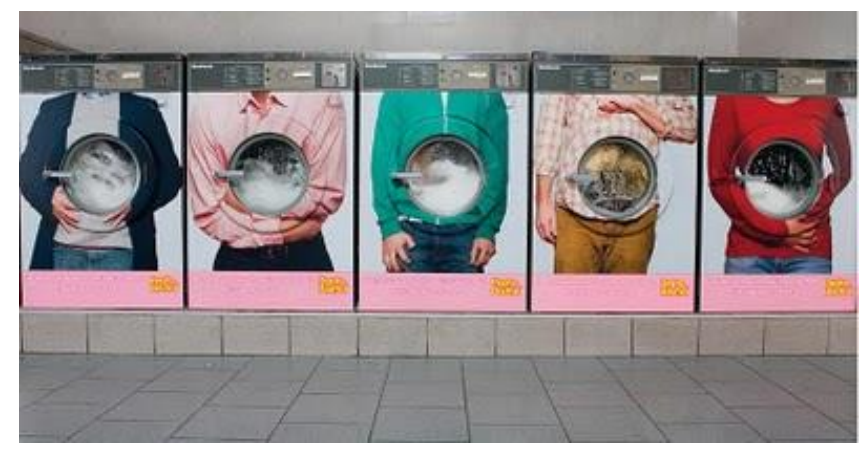

Figura $2-$ PeptoBismol $^{5}$.

Se nos detivermos ao elemento visual, percebemos que as mãos dos corpos das pessoas retratadas coladas nas máquinas são indicativas de alguma espécie de desconforto: um rapaz vestindo uma blusa verde aperta a calça como sinal de dor. Também é possível identificar que as pessoas estão com as mãos em torno da região estomacal, o que salienta o

\footnotetext{
5 Disponível em: <https://www.adsoftheworld.com/media/ambient/peptobismol_laundromat>. Acesso em: 30 mar. 2011.
} 
visor transparente da máquina, por onde se pode ver a espuma do sabão e as roupas em movimento.

O elemento verbal também trabalha em sintonia com o suporte. Abaixo de todas as fotos, está escrito: No matter what you throw in your stomach. Pink's got you covered. (Não importa o que você jogue no estômago. O rosa ${ }^{6}$ protege você). Faz parte do conhecimento de mundo dos consumidores que a maioria dos problemas relacionados à azia e à má digestão é causada por algum alimento gorduroso, forte em temperos etc. Assim, o elemento verbal, que diz que "Não importa o que você jogue no seu estômago" recorre ao conhecimento de mundo, de que uma das funções da lavadora de roupas é exatamente a de lavar qualquer tipo de roupa que seja jogada dentro dela. E, da mesma forma como a máquina lava as roupas, o remédio "limpa" o estômago de todo o desconforto. Podemos perceber que o texto só é coerente e exerce sua intenção argumentativa a partir dos seus aspectos pragmáticos. Somente o elemento verbal e/ou o elemento imagético não seriam suficientes para a constituição da coerência. Essa coerência - e, portanto, possibilidade de produção de sentidos - só se estabelece a partir da integração da peça com a função do objeto sobre o qual ela está instalada - o suporte, que é constituinte do sentido.

Já a Figura 3 mostra a peça publicitária criada para a faculdade $\mathrm{ESIC}^{7}$, um centro universitário com foco na área de negócios e administração de empresas. A peça é constituída de um adesivo colado a um espelho, simulando a capa de uma revista, que na propaganda se chama "Fortuna".

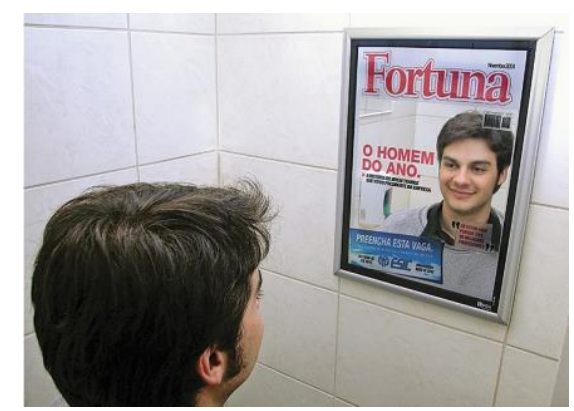

Figura 3 - Adesivo em espelho

A imagem da pessoa que utiliza o banheiro, ao ser refletida no espelho, é emoldurada pelo adesivo, que simula a capa da revista, com chamadas relativas ao assunto de interesse do público-alvo: como ser bem-sucedido na vida profissional. Percebemos nesta peça o elemento

\footnotetext{
${ }^{6}$ Em referência à cor do medicamento, cor-de-rosa.

${ }^{7}$ A ESIC (Escuela Superior de Ingenieros Comerciales) é uma escola de negócios espanhola, que também tem sede no Brasil, em Curitiba, PR.
} 
de intertextualidade com a revista americana Fortune, que trata de negócios e traz na capa de todas as edições fotos de personalidades do mundo empresarial. Entre a peça criada para a faculdade ESIC e a revista na qual é inspirada, há vários elementos de intertextualidade de conteúdo, que, conforme Koch (2008), trata-se da imitação ou paródia tendo em vista efeitos específicos, estilos, registros ou variedades de língua, como a reprodução da linguagem de dado escritor ou de um dado segmento da sociedade, como aqui, nas revistas de negócios.

Verificamos também a intertextualidade no que tange à forma, pelo fato de a propaganda apresentar elementos visuais bastante similares aos da revista, como o título, que ocupa toda a parte superior da página, além das fontes tipográficas e a distribuição das palavras nas manchetes. Já em relação ao personagem retratado, verifica-se que a intenção da propaganda é imitar o retrato de um profissional de negócios: quando o usuário do banheiro se posiciona à frente do espelho, é a sua imagem, refletida, que ocupa a posição que ocuparia a personalidade na revista. Essa integração do usuário do banheiro com a "moldura" proporcionada pela peça publicitária, que simula a aparência da capa, deve-se à característica do espelho, ou seja, do suporte em que a peça está fixada.

Essa relação é reforçada pelo elemento textual no adesivo. A primeira "manchete", que traz as frases "O homem do ano. A história do jovem trainee que virou presidente da empresa", imita uma manchete de revistas de negócios. Outro elemento verbal faz referência a um depoimento que poderia ter sido dado por um profissional de negócios em uma entrevista, entre aspas, como se estivesse em discurso direto ("Só estou aqui porque tive os melhores professores"), fazendo, novamente, uma relação intertextual com publicações jornalísticas relativas a negócios. Essa frase é também um elemento que reforça a característica persuasiva desse texto, pois apresenta uma das qualidades da escola, os bons professores, contribuindo para a argumentação sobre o produto anunciado.

Finalmente, na parte inferior do adesivo, apresenta-se o que seria outra manchete, mas que, na verdade, é um elemento com características claramente persuasivas: "Preencha esta vaga. Faça Gestão de Negócios e Marketing na ESIC. Inscreva-se até 30/11”. Verificamos um duplo sentido na frase "Preencha esta vaga", que poderia tanto dizer respeito ao preenchimento de uma vaga de emprego, que levaria o indivíduo retratado no espelho a ser o "homem do ano", um objeto de desejo distante, mas que poderia ser atingida por meio daquele produto anunciado (o ensino oferecido pela faculdade), quanto à própria vaga na faculdade, uma posição muito mais atingível, que ele pode conquistar com mais facilidade, a começar fazendo a inscrição no curso. 
O fato de essa propaganda ter como suporte um espelho é fundamental para a sua constituição textual. Ao se ver refletido e emoldurado "em uma capa de revista" por manchetes referentes ao sucesso, o consumidor tem a oportunidade de se ver também nesse grau de sucesso que a escola promete. Assim, o suporte age como um elemento fundamental para a intertextualidade e, por consequência, para a argumentatividade do texto. A coerência se cria a partir da fusão de todos esses elementos: as características visuais do adesivo, os aspectos verbais e o reflexo, que entra como um elemento pragmático nessa relação.

O suporte pode servir à mídia de ambiente como uma forma de distorcer a percepção sobre o que é real e o que não é, levando o consumidor a olhar com mais atenção para um texto. Na propaganda apresentada a seguir (Figura 4), podemos ver a utilização da técnica de ilusão (HIMPE, 2006) em uma peça da International Foundation for Human Rights (em português, Fundação Internacional pelos Direitos Humanos), que apresenta a imagem de uma mulher sendo torturada impressa sobre um capacho, de forma bastante realista.

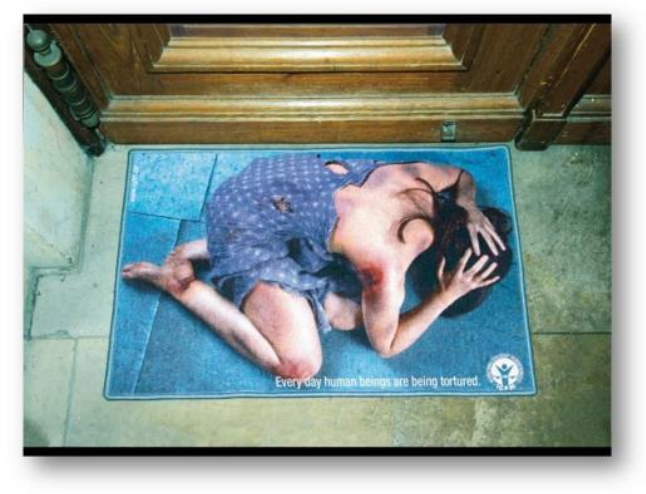

Figura 4 - Capacho Human Rights. ${ }^{8}$

Ao se deparar com a imagem, o indivíduo pode se surpreender, sendo necessário olhar novamente para compreender que é apenas uma ilusão. Neste caso, o suporte, além de atípico, por ser um capacho, permite que haja ainda uma interação física do destinatário com a propaganda, pois ele vai pisar nela. Ao limpar os pés, o indivíduo mimetiza o ato da tortura sobre a mulher e, como o capacho não é um lugar onde se espera que exista propaganda, esse ato também pode causar surpresa, pois indivíduo pode perceber que está pisando sobre uma imagem (bastante realista) somente depois de começar a realizar movimentos, que normalmente são fortes ou bruscos.

\footnotetext{
${ }^{8}$ HIMPE, 2006, p. 130.
} 
É nesse momento que o suporte passa a ter forte influência sobre a produção de sentidos, pois quem limpa os pés acaba por ocupar o papel do torturador na relação com esse texto. O movimento dos pés, combinado à ilusão inicial, traz o elemento de impacto da propaganda, o que, consequentemente, tem um papel importante na constituição da argumentatividade do texto. A fotografia retrata uma pessoa se defendendo, provavelmente, de um agressor. Neste caso, a pessoa que pisa no tapete é, de certa forma, colocada nesse papel, o que reforça ainda mais o poder que a participação desse receptor tem na argumentatividade e na constituição da coerência para a produção de sentidos nessa propaganda. O elemento verbal Every day human beings are being tortured (Todos os dias seres humanos são torturados) somado a posição em que a propaganda coloca o seu consumidor atribuem sentidos de que estas situações estão mais próximas e são mais comuns do que imaginamos. É o suporte escolhido - o capacho em que se pisa, metonimicamente representando o próprio ser humano agredido - que propicia a força argumentativa da propaganda contra atos de agressão e a colocação do indivíduo na posição de agressor, de onde decorrerem as reflexões pretendidas pelo anunciante.

\section{Suporte como fator de coerência}

A peças publicitárias de mídia de ambiente analisadas demonstram nossa ideia de que o suporte, nessa mídia, desempenha um papel mais do que acessório, de mero portador textual, ele é um dos elementos fundamentais na constituição dos sentidos e da coerência dos textos, sendo considerado, inclusive, um elemento necessário para a sua constituição. Partimos do princípio de que, quando se trata de analisar textos, é fundamental considerar a forma como eles são veiculados, como eles se tornam acessíveis às pessoas às quais são dirigidos, seu lócus físico - o que entendemos como suporte.

Podemos afirmar que o sucesso na coerência textual das peças publicitárias analisadas está fortemente embasado no suporte que, em todos os casos, faz parte da constituição da textualidade, não podendo ser dispensado. Por entendermos que o suporte seja um elemento constituinte da coerência textual, propomos uma adaptação do diagrama de Koch e Travaglia (2011), conforme apresentado na Figura 5. No diagrama dos autores, o suporte é considerado como um elemento da situacionalidade ou dos fatores pragmáticos, quando estes dizem respeito também às condições físicas de produção do entorno do texto. No entanto, nossa proposta é a de que, ao tratarmos da mídia de ambiente, o suporte merece lugar de destaque 
nesse diagrama, pois exerce papel fundamental na construção dos sentidos e, portanto, da coerência em textos publicitário dessa mídia.

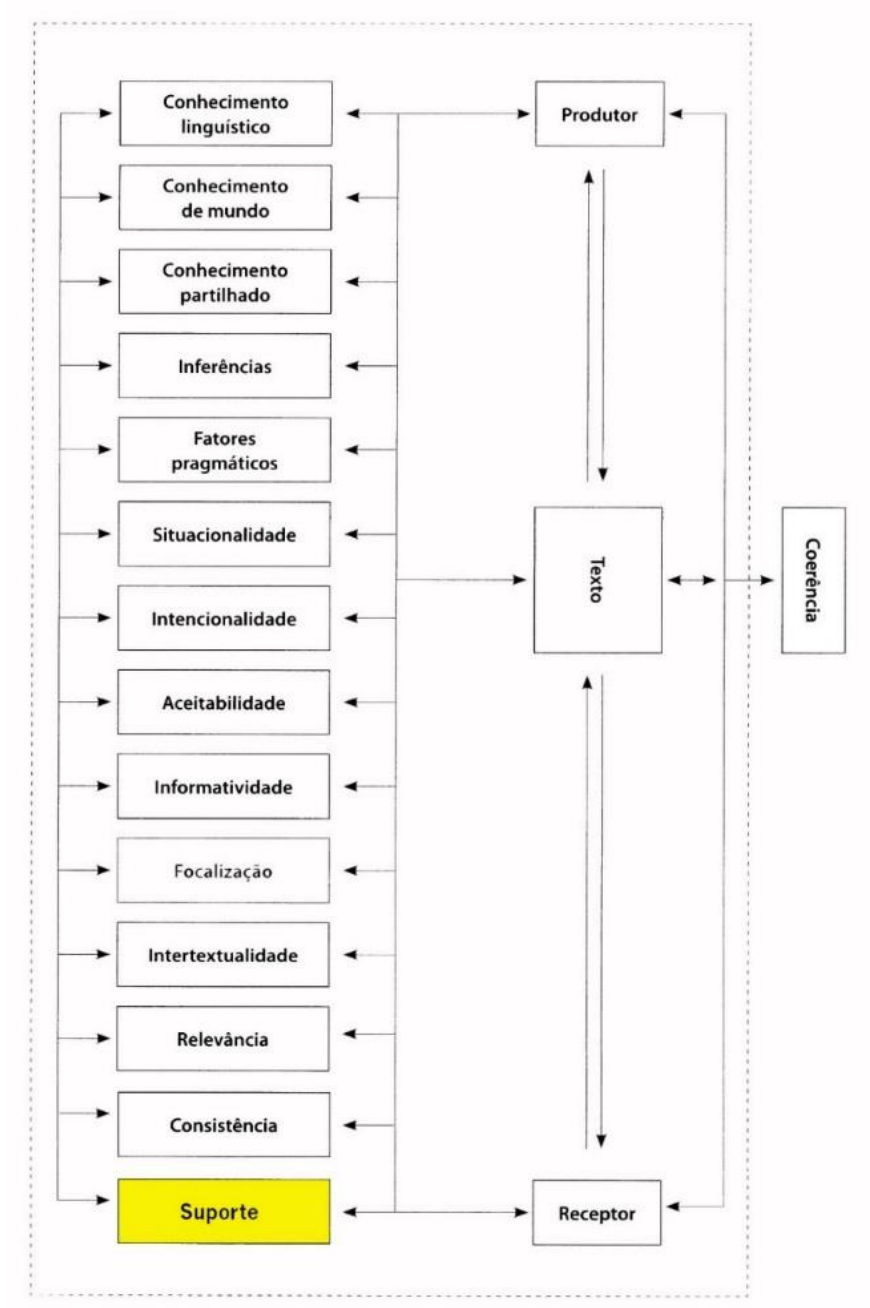

Figura 5 - Adaptação do diagrama de Koch e Travaglia (2011).

\section{Conclusão}

O diagrama que apresentamos no presente artigo inclui o suporte como um elemento adicional dos fatores convocados para a constituição da coerência textual. Esse acréscimo deve-se ao fato de vermos o suporte como um dos elementos fundamentais para a produção dos sentidos e da coerência nos textos de mídia de ambiente. Em nossas análises, entendemos que a coerência exerce o seu papel de elemento macro na produção de sentidos, sendo, portanto, um "critério agregador" que abarca todos os outros elementos fundamentais para a interação entre texto, produtor e receptor. 
Acreditamos na necessidade da inclusão do suporte entre os fatores de coerência da mesma forma como acreditamos que outros elementos possam vir a surgir, em pesquisas futuras, como necessários na constituição do sentido que os usuários constroem no/a partir dos textos aos quais têm acesso.

\section{REFERÊNCIAS}

BEAUGRANDE, R.-A. de \& DRESSLER, W. Introduction to text linguistics. London: Longman, 1981.

BEAUGRANDE, Robert de. New Foundations for a Science of Text and Discourse. University of $1997 . \quad$ Dienna, em: http://www.beaugrande.com/new_foundations_for_a_science.htm. Acesso em: 06 jul 2012.

BEZERRA, Benedito Gomes. Do manuscrito ao livro impresso: investigando o suporte. CAVALCANTE, Mônica; et al. Texto e discurso sob múltiplos olhares, v. 1, p. 837, 2006.

BONINI, Adair. Mídia/suporte e hipergênero: os gêneros textuais e suas relações. Revista Brasileira de Linguística Aplicada, v. 11, n. 3, 2011. Disponível em: http://www.scielo.br/pdf/rbla/v11n3/05.pdf Acesso em 26 mar. 18.

. Os gêneros do jornal: questões de pesquisa e ensino. In: KARWOSKI, A. M.; GAYDECZKA, B.; BRITO, K. S. (Org.). Gêneros textuais: reflexões e ensino. 2. ed. Rio de Janeiro: Lucerna, 2006 [2005: Editora Kaygangue]. p. 57-71.

CAVALCANTE, Mônica Magalhães. Os sentidos do texto. São Paulo: Contexto, 2012. ; CUSTÓDIO FILHO, Valdinar. Revisitando o estatuto do texto. Revista do

GELNE, v. 12, n. 2, p. 56-71, 2010.

CHAROLLES, Michel. Coherence as a principle in the interpretation of discourse. In: T. A. VAN DIJK (Ed.), Text. Vol. 3 (1), pp. 71-99. Amsterdam: Mouton Publishers, 1983.

COSTA, Iara Bemquerer. Contribuições ao debate sobre a relação entre gênero textuais e suporte. Revista Letras, Curitiba: Editora UFPR, n.75/76, p. 183 - 196, 2008.

COVALESKI, R. Ambient media e espacialidade urbana. In: XXXI Congresso Brasileiro de Ciências da Comunicação, 2008, Natal, RN. Anais... Natal: Intercom - Sociedade Brasileira de Estudos Interdisciplinares da Comunicação, 2008, p. 1-14.

. Publicidade Híbrida. Curitiba: Maxi Editora, 2010.

DEBRAY, R. Curso de midiologia geral. Petrópolis: Vozes, 1993 [1991].

FÁVERO, L. L., KOCH, I . G. V. Critérios de textualidade. Veredas, v. 104, p. 17-34,1985. . Linguística textual: introdução. 2 ed. São Paulo: Cortez, 1988.

$\mathrm{KOCH}$, Ingedore Grunfeld Villaça. O texto e a construção dos sentidos. 9 ed. $1^{\text {a }}$ reimpressão. São Paulo: Contexto, 2008.

Introdução à linguística textual: trajetória e grandes temas. 2 ed. São Paulo: WMF

Martins Fontes, 2009.

. TRAVAGLIA, Luiz Carlos. Texto e coerência. 13 ed. São Paulo: Cortez, 2011.

HIMPE, Tom. Advertising is dead. Long live advertising! Londres: Thames \& Hudson, 2006.

MARCUSCHI, Luiz Antonio. A questão do suporte dos gêneros textuais. Projeto Integrado: "Fala e Escrita: Características e Usos", NELFE (Núcleo de Estudos Linguísticos da Fala e Escrita), Departamento de Letras da UFPE, 2003. 
Editorial, 2008.

Produção textual, análise de gêneros e compreensão. São Paulo: Parábola MAINGUENEAU, Dominique. Análise de textos de comunicação. $6^{\text {a }}$ Ed. São Paulo: Cortez, 2013.

McLUHAN, M. Os meios de comunicação como extensões do homem (understanding media). São Paulo: Cultrix, 2002 [1964].

PÚBLIO, Marcelo. Como planejar e executar uma campanha de propaganda. São Paulo: Atlas, 2008.

ROMUALDO, E. C. Charge jornalística: intertextualidade e polifonia. 1. ed. Maringá: EDUEM, 2000. v. 1. 205p.

Propaganda em banheiros: produção de sentidos na mídia indoor. In: Esther Gomes de Oliveira; Hertez Wendel de Camargo. (Org.). Linguagem \& publicidade. 1ed.Londrina: Syntagma Editores, 2013, v. 1, p. 162-174.

. Análise de textos verbo-visuais: polifonia, intertextualidade e polêmica na divulgação da parada LGBT de Maringá/2012. In: Letícia Marcondes Rezende; Odair Luiz Nadin da Silva; Marina Célia Mendonça; Claudia Zavaglia; Anna Flora Brunelli. (Org.). A interdisciplinaridade e a especificidade linguística: teorias e práticas. 1ed.São Paulo: Cultura Acadêmica, 2014, v. 26, p. 135-155.

Recebido em 31/03/2018. Aceito em 06/06/2018. 